Edited 16.01.2020]. Available at: https://zakon.rada.gov.ua/laws/show/2145-19 (in Ukrainian)

7. Zakon Ukrainy «Pro profesiinu (profesiino-tekhnichnu) osvitu» vid 10.02.1998 r. 103/98-VR. Redaktsiia vid 01.01.2019 [Law of Ukraine on Vocational Education dated 10.02.1998. № 103/98-VR. Edited 01.01.2019]. Available at: https://zakon.rada.gov.ua/laws/show/103/98-\%D0\%B2\%D1\%80 (in Ukrainian)

8. Konventsiia pro vyznannia kvalifikatsii z vyshchoi osvity v yevropeiskomu rehioni vid 11.04.1997 r. Ratyfikatsiia vid 03.12.1999 r [Convention on the Recognition of Higher Education in the European Region dated 11.04.1997. Edited 03.12.1999]. Available at: http://zakon.rada.gov.ua/laws/ show/994_308 (in Ukrainian)

9. Nychkalo, N. Osoblyvosti rozvytku ukrainskoi profesiinoi osvity: dosvid, superechnosti, perspektyvy [Peculiarities of Ukrainian vocational education development: experience, contradictions, perspectives]. Available at: http://lib.iitta.gov.ua/711220/1/63.pdf (in Ukrainian)

10. Sushchenko, L. P. (2003). Profesiina pidhotovka fakhivtsiv fizychnoho vykhovannia ta sportu (teoretyko-metodolohichnyi aspect) [Professional training of physical education and sports specialists (theoretical and methodological principles)]. Zaporizhzhia: Zaporizhzhia State University, 442 p. (in Ukrainian)

\title{
USING AUTHENTIC TEXTS FOR CLIL LESSONS AT UNIVERSITY
}

\section{Olha Zavorotna ${ }^{1}$}

DOI: https://doi.org/10.30525/978-9934-588-39-6-4

Nowadays higher education in Ukraine works towards integration and cross-curricular connections which is possible to provide only through a special method of teaching a language that would reflect the reality in which the learners live and work. Thus the implementation of CLIL approach at university is in demand.

According to Marsh, CLIL is «any dual-focused educational context in which an additional language, thus not usually the first language of the learners involved, is used as a medium in the teaching and learning of nonlanguage content» [2, p. 14].

CLIL approach allows two subjects to be taught simultaneously, although the focus may be on the language or a non-linguistic subject [1, p. 154].

Owing to the CLIL approach, language learning becomes more focused as language is used to solve specific communication problems. Moreover, students become more motivated to learn English.

${ }^{1}$ National Technical University of Ukraine «Igor Sikorsky Kyiv Polytechnic Institute», Ukraine 
Despite the advantages of this approach and its relevance, the researchers point to the lack of study materials. In the CLIL methodology reading is considered as the main skill and this approach involves working with text material. Since the authentic professional material is the main source of introduction of new professional terms, CLIL lessons are usually based on the authentic subject-matter texts.

There is a variety of definitions of the term «authentic» so we will be referring to the Nosonovich`s definition: «Authentic materials are materials that have been created by native speakers and found the implementation in a learning process which is focused on a communicative approach of learning a foreign language outside their native linguistic environment» [3, p. 10].

In the CLIL methodology studying with authentic material is of great importance. It should be noted that the use of authentic materials is necessary at all stages of learning a foreign language. However, when students study academic subjects in another language, they will need a teacher`s assistance in understanding subject matter texts and in learning to use the academic language associated with the subject.

The need for authentic materials is due to a number of the following reasons. Firstly, authentic texts have features that are often not reflected in educational texts and dialogues. They may contain specific terminology, professional jargon, specific models for constructing phrases and sentences. The authentic text is based on the real language that the students will have to encounter in a professional activity. Moreover, the students will be able to develop the skills of understanding and reproduction of the subject-specific vocabulary. Secondly, written and oral texts taken from real life provide accurate information about real events and situations. Provided that recent, up-to-date sources are used, this information will always be accurate. In addition, these sources are usually of high professional interest to English language learners, because, as mentioned above, they contain information directly related to their field of activity.

There are still some challenges that students may be faced with while learning by means of authentic texts. The authentic subject-matter texts are sophisticated and are likely to be difficult to understand for less proficient students. The teacher`s role is highly important here. The teacher does not have to adapt the text, but it is possible to help students to understand the text by the following steps.

1) The teacher should pre-teach some difficult vocabulary in order to prepare students for the first reading and prevent blocking understanding of the main idea of the text.

2) The next step is to prepare the questions which will help to check the general understanding of the text. 
3) Finally, the teacher has to prepare the questions to check whether students have understood the text in more details.

As a result, students will be better able to reproduce the content of the texts in their own words. All of the stages above will help students to understand the context of the subject matter texts and prepare them for further content learning. It is considered appropriate to accompany the texts with illustrations so that students can visualize what they are reading.

To sum up, CLIL lessons have a lot of advantages compared to traditional education at universities. Authentic texts which are used in this approach are effective means of studying both the subject and the language however they might be sophisticated for the low proficient students. Nevertheless, with the teacher`s guidance and support, it will become an effective source of learning.

\section{References:}

1. Larsen-Freeman, D., \& Anderson, M. (2011). Techniques and principles in language teaching. Oxford: Oxford University Press.

2. Marsh, D. (2012). Content and Language Integrated Learning (CLIL). A Development Trajectory. Córdoba: University of Cyrdoba.

3. Nosonovich, E. V. (2000). Metodicheskaya autentichnost' v obuchenii inostrannym yazykam [Methodological authenticity in teaching foreign languages]. Foreign languages at school, no. 1, pp. 11-16.

\section{THE DIVERSIFICATION OF HIGHER EDUCATION AS A GLOBAL TREND OF MODERNITY}

\section{Alla Ziakun ${ }^{1}$ \\ DOI: https://doi.org/10.30525/978-9934-588-39-6-5}

The education system, like the culture of its people, is a unique phenomenon because it is deeply linked to the spiritual and material aspects of the past and present. Therefore, in every country, education and its organization have its own peculiarities. In today's world of globalization, priorities and demands for learning and upbringing are changing. Therefore, higher education reform is inevitable. However, on the one hand, it is necessary to take into account the priorities of preserving the cultural diversity of national education systems, and on the other hand, to solve the problems of improving international cooperation, mobility, employment of students in the

${ }^{1}$ Sumy State University, Ukraine 